\title{
Roles of viral infection in organic particle flux
}

\author{
L. M. Proctor ${ }^{1,2}$, J. A. Fuhrman ${ }^{2}$ \\ ${ }^{1}$ Marine Sciences Research Center, State University of New York at Stony Brook, Stony Brook, New York 11794-5000, USA \\ ${ }^{2}$ Department of Biological Sciences, University of Southern California, Los Angeles, California 90089-0371, USA
}

\begin{abstract}
Lack of information on the fate of particulate-associated microorganisms prompted this investigation of viruses (including bacteriophage or phage) and phage-infected cells in sinking particles from sediment traps. Sediment trap material from 30 to $400 \mathrm{~m}$ collected from the north Pacific Ocean during the 'VERTEX' cruises in 1980 to 1982 was examined by transmission electron microscopy. Viruses were present in all of the sinking particles examined except for those from one sample, of highly degraded algal cells or small fecal pellets, from $400 \mathrm{~m}$. Viruses in the sinking particles often appeared aggregated. From 0.7 to $3.7 \%$ of the bacteria in sinking particles contained mature phage; from these data and limited information from pure cultures, we estimate that 2 to $37 \%$ of the particulate-associated bacteria may be killed by viral lysis. Many eukaryotic cells were also apparently infected with viruses, but none ( $\leq 50$ cells observed) of the cyanobacteria or 'Chlorella-like' cells appeared infected. Viral lysis of bacteria associated with sinking particles and free-living bacteria may be causally linked and may play a role in dissolved organic carbon production and the dynamics of sinking particles. Viral lysis may have major implications for understanding cycling of material and energy in the ocean.
\end{abstract}

\section{INTRODUCTION}

A variable but significant portion of the surfacederived production in the oceans leaves the upper mixed layer in the form of fecal pellets and marine snow (Alldredge \& Silver 1988). Microorganisms may play a major role in controlling the flux of these particles (Cho \& Azam 1988) and although all particulate matter in the ocean appears to contain associated bacteria (Riley 1970), little is known about the fate of these particulate-associated bacteria. Some studies have been initiated to understand the potential importance of protozoa in attached bacterial mortality (Pomeroy et al. 1984, Silver et al. 1984, Caron et al. 1986). However, virus-induced lysis has yet to be investigated as a cause of mortality in microbial communities on sinking particles.

Marine viruses have been observed for several decades in culture (e. g. Kriss \& Rukina 1947, Spencer 1963, Chaina 1965, Johnson 1968, Ahrens 1971, Hidaka 1971, 1977, Kakimoto \& Nagatomi 1972, Baross et al. 1978, Zachary 1978, Moebus \& Nattkemper 1981), and by microscopy (e.g. Sieburth 1979, Torrella \& Morita 1979, Sieburth et al. 1988). Recent reviews on marine bacterial mortality have suggested phage as potentially important agents of mortality (McManus \& Fuhrman 1988, Pace 1988). The first direct counts of total virus abundances, by transmission electron microscopy (TEM) were reported by Torrella \& Morita (1979), who observed more than $10^{4}$ viruses $\mathrm{ml}^{-1}$ of seawater. More recent estimates indicate that virus abundances range from $10^{5}$ to $10^{8} \mathrm{ml}^{-1}$ of seawater (Proctor et al. 1988, Bergh et al. 1989, Børsheim et al. 1990, Bratbak et al. 1990, Proctor \& Fuhrman 1990). However, high virus abundance alone does not indicate its importance in the food web, because of uncertainty about hosts, sources, inactivation rates or other factors in viral ecology. Proctor \& Fuhrman (1990) investigated viral mortality of marine microorganisms by examining sectioned cyanobacteria and heterotrophic bacteria for the presence of phage inside the host, and estimated that up to between 30 and $60 \%$ of total mortality may be attributed to viral lysis. Other reports indicate that marine viruses may also be important in phytoplankton mortality (Pienaar 1976, Mayer \& Taylor 1979, Sieburth et al. 1988, Suttle et al. 1990). Viral mortality has even been suggested for the mass extinctions of coccolithophorids, Foraminifera and Radiolaria observed in deep-sea sediment cores from the late Cenozoic (Emiliani 1982).

Viruses, microorganisms, and sinking particles may interact in several ways that can have major impacts in marine systems. Viruses in seawater survive longer when adsorbed to particulate matter such as sinking 
particles (reviewed in Gerba \& Schaiberger 1975, Kapuscinski \& Mitchell 1980). Sinking particles may be a site where free-living bacteria encounter infectious viruses, or infectious viruses may be released into the surrounding water by reversible desorption from the sinking particles. In addition, many other factors influencing virus survival and phage/host encounter in seawater, including virus aggregation (Young \& Sharp 1977), and the presence of high concentrations of macromolecules such as dissolved proteins (Lycke et al. 1965), are all likely to be enhanced in sinking particles. Viral mortality also results in the release of high molecular weight cellular constituents and the release of these cellular components can act as biological glues to enhance sinking particle formation (reviewed in Harris \& Mitchell 1973, Alldredge \& Silver 1988). All of these factors may play important roles in the dynamics of sinking particles and viral mortality of planktonic microorganisms.

Here we present evidence from TEM of viruses, phage-infected and virus-infected cells in sinking particles collected from sediment trap material. We discuss the significance of viral mortality of microorganisms and the implications of viral lysis on dissolved organic carbon (DOC) production and on formation/dissolution of sinking particles.

\section{MATERIALS AND METHODS}

Sinking particles, including various types of fecal pellets in addition to amorphous aggregates (marine snow-like material), were collected in drifting, particle interceptor Multitraps (Knauer et al. 1979) deployed for 13 to $22 \mathrm{~d}$ in the northeastern Pacific Ocean (Martin et al. 1987) at VERTEX (Vertical Transport and Exchange of Materials in the Upper Waters of the Ocean) stations (Table 1). Traps were filled with a preservative solution of $2 \%$ glutaraldehyde in borate-buffered seawater $(\mathrm{pH}$
7.4) with $18 \%$ sucrose added as a high density solution to retain sediment trap material during trap recovery (Gowing \& Silver 1985). Various preservatives were tested and this concentration of preservative effectively stopped all bacterial autolytic and metabolic processes in the traps (Gowing \& Silver 1983). Plankton tows on the same cruises harvested zooplankton and zooplankton pellets, the contents of which were compared to the sediment trap material.

Trap and tow materials were prepared for TEM as described by Silver \& Alldredge (1981). Ultrathin (60 to $90 \mathrm{~nm}$ ) sections were post-stained with $2 \%$ aqueous uranyl acetate/lead citrate and viewed on a Philips 300 transmission electron microscope at $80 \mathrm{kV}$. Bacteria in clusters within particulate matter were enumerated with morphological types noted. Phage were identified as strongly-staining intracellular polygonal structures which appeared to be composed of distinct protein coats surrounding cores of nucleic acid. Bacteria with 3 or more intracellular phage were scored as infected. The presence of viruses and virus-infected eukaryotes was noted. Viruses outside cells were not enumerated because sections were not randomly sampled but biased towards bacterial clusters. One hundred or more bacterial cells were enumerated from each depth, and particle types (with at least 7 replicate counts) were scored to estimate variability in the percentage of infected bacteria.

\section{RESULTS}

Both tailed and nontailed viruses, some with elaborate antennae and ranging in diameter from 50 to $400 \mathrm{~nm}$, were observed in all the VERTEX sinking particle samples examined (Fig.1) except in the material from $400 \mathrm{~m}$, which comprised material previously called 'olive-green cells' (Fournier 1970), now judged to be either highly degraded algal cells (Silver

Table 1. Location, depth, date and sampling method of VERTEX TEM samples

\begin{tabular}{|c|c|c|c|c|c|}
\hline Station & $\begin{array}{c}\text { Surface water } \\
\text { temp. }\left({ }^{\circ} \mathrm{C}\right)\end{array}$ & Location & Depth (m) & Date & Sampling method \\
\hline VERTEX I & $13-15$ & $35.7^{\circ} \mathrm{N}, 123.8^{\circ} \mathrm{W}$ & 50 & 26 Aug-8 Sep 1980 & Trap \\
\hline \multirow{2}{*}{ VERTEX II } & $26-28$ & $17.8^{\circ} \mathrm{N}, 108.0^{\circ} \mathrm{W}$ & 30 & 27 Oct-17 Nov 1981 & Trap \\
\hline & & & 120 & 27 Oct-17 Nov 1981 & Trap \\
\hline \multirow[t]{6}{*}{ VERTEX III } & $28-30$ & $15.7^{\circ} \mathrm{N}, 107.5^{\circ} \mathrm{W}$ & 60 & $9-30$ Nov 1982 & Trap \\
\hline & & & 80 & 9-30 Nov 1982 & Trap \\
\hline & & & 120 & 9-30 Nov 1982 & Trap \\
\hline & & & 140 & $9-30$ Nov 1982 & Trap \\
\hline & & & 400 & 9-30 Nov 1982 & Trap \\
\hline & & & $100^{a}$ & $9-30$ Nov 1982 & Tow \\
\hline
\end{tabular}


\& Bruland 1981) or small fecal pellets (Gowing \& Silver 1985). Viruses often appeared in clusters or aggregated with the remains of host cells (Fig. 1).

The most noteworthy feature of the distribution of phage-infected bacteria in the sinking particle samples examined is the widely variable percentage of infected bacteria. From 0.7 to $3.7 \%$ of the heterotrophic bacteria in the sinking particles contained mature phage (Table 2). Phage-infected bacteria were present in sinking particles that included fecal pellets from a broad variety of zooplankton as well as in sinking particles from unidentifiable sources (Fig. 2). Fresh salp pellets from plankton tows contained more phage-infected bacteria than zooplankton pellets from sediment traps (Table 2). Bacteria of all morphological types contained phage particles (Fig. 2) except the cells, with intracellular lamellae, thought to be methyltrophs (Gowing \& Silver 1985). The methylotrophs often appeared lysed without the apparent presence of viruses. This may have been due to a preparation artifact, although there were intact cells adjacent to lysed cells (Fig. 2).

Phytoplankton less than $2 \mu \mathrm{m}$ in diameter are relatively abundant in sinking particles $\left(10^{3}\right.$ to $10^{5}$ aggregate $^{-1}$; Alldredge \& Silver 1988). Approximately 20 to 50 of each cell type were enumerated but none of the recognizable cyanobacteria and 'Chlorella-like' phytoplankton present in sinking particles (Gowing \& Silver 1985) appeared to be infected with viruses. Although the larger eukaryotic cells were not enumerated because of low overall abundances, numerous larger phytoplankton, including diatoms with intact frustules, contained virus particles (Fig. 3).

\section{DISCUSSION}

Only the final stage of phage maturation prior to host cell lysis is visible by transmission electron microscopy. In order to estimate the actual percentage of infected bacteria present at all stages of phage infection from TEM data, a correction must be made for that portion of the latent period when the phage are not visible. Previous TEM studies of morphological changes in phageinfected bacteria provide the only data currently available for this purpose. However, such studies are rare and the data are not ideally suited, usually due to an insufficient number of points sampled. Here we briefly summarize these findings and use them to make our estimates. In Escherichia coli infected with T2 phage, small numbers of mature phage begin to appear after $47 \%$ of the latent period (between infection and lysis) has elapsed (Kellenberger et al. 1959). Valentine \& Chapman (1966) showed in a phage-infected marine bacterium (Cytophaga marinoflava) that mature phage begin to appear after $57 \%$ of the latent period had elapsed. However, the authors noted that only 40 to $50 \%$ of the cells contained small numbers of mature phage at this time point while 85 to $90 \%$ of the cells each contained many phage when $86 \%$ of the latent period had elapsed. Finally, in E. coli infected with T5 phage, mature phage are not visible when $67 \%$ of the latent period has elapsed but are visible virtually at the point of cell lysis (Kellenberger 1961).

From these data, we estimated correction factors as the ratio of the full latent period to the time over which mature phage are readily visible in the cells. For a low estimate of the correction factor, we chose the earlier timepoint of Valentine \& Chapman (1966), which yields a value of $2.33(1 /[1-0.57])$. Clearly this is low because less than $50 \%$ of the infected cells showed any intracellular phage at this time and those that did had only a few. The correction factor assumes $100 \%$ of the infected cells have visible phage at the indicated time point. For our high estimate, we chose a factor of 10.0 $(1 /[1-0.9])$, which is slightly higher than the value implied by the later time point of Valentine \& Chapman (1966); we used the slightly higher value (90\% of the latent period instead of $86 \%$ ) because: (1) not all the cells showed intracellular phage at this time point and (2) comparison of Valentine \& Chapman's data to Kellenberger's (1961) data on Escherichia coli infected with T5 phage suggest that some phage may assemble quite late. We believe the higher numbers are more appropriate when there are relatively large numbers of mature phage within the phage-infected marine bacteria, as previously observed in the plankton (Proctor \& Fuhrman 1990). Furthermore, it is possible the higher values may be more appropriate for marine bacteria because natural bacteria are much smaller than cultured ones, so that in natural bacteria a larger percentage of the biomass needs to be in the form of mature phage for the phage to be visible by TEM. Application of both the low and high correction factors to our TEM data (Table 2) indicates that from 2 to $37 \%$ of particulate-associated bacteria are likely to be at some stage of phage infection. Better estimates of the correction factors await more detailed TEM studies of marine phage/host systems; such work is currently in progress in our laboratory.

Bacterial abundances from diver-collected organic aggregates (Alldredge \& Silver 1988) were applied to our TEM data to estimate the abundances of phageinfected bacteria in sinking particles. Typical bacterial abundances in sinking particles from near-surface waters ( 0 to $25 \mathrm{~m}$ ) average $5.7 \times 10^{6}$ aggregate $^{-1}$ and in deeper waters ( 30 to $1650 \mathrm{~m}$ ) average $8.3 \times 10^{6}$ aggregate $^{-1}$ (from Table 5 of Alldredge \& Silver 1988). Sinking particles from near-surface waters average 2.9 aggregates $1^{-1}$ of seawater while sinking particles from deeper waters average 0.6 aggregates $1^{-1}$ of seawater 

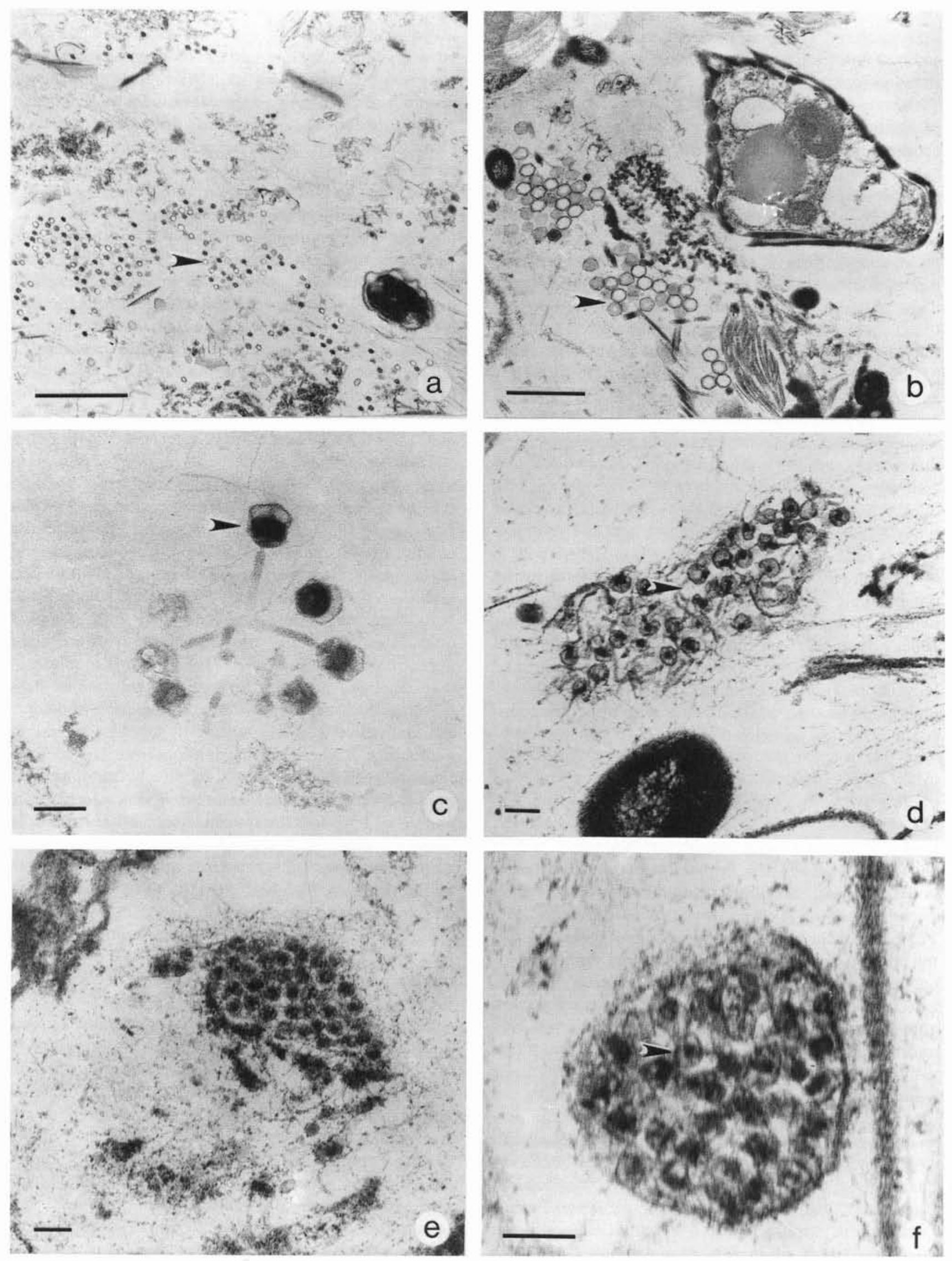
Table 2. Distribution of phage-infected heterotrophic bacteria in sinking particles determined by transmission electron microscopy. Data expressed as mean percentage (and range) of phage-infected cells observed in sinking particles with the number of replicate subsets and total number of cells enumerated from each depth and particle type presented. Origin of sinking particle indicated where known

\begin{tabular}{|c|c|c|c|c|c|}
\hline Date & Depth (m) & Particle type $^{a}$ & No. of subsamples & No. of cells & $\%$ Infected \\
\hline 26 Aug-8 Sep 1980 & 50 & Zooplankton pellet & 15 & 205 & $2.7(0-9.1)$ \\
\hline 27 Oct-17 Nov 1981 & 30 & Aggregate-like material & 9 & 107 & $3.1(0-11.1)$ \\
\hline 27 Oct-17 Nov 1981 & 120 & Aggregate-like material & 8 & 107 & $1.3(0-10)$ \\
\hline 9-30 Nov 1982 & 60 & Aggregate-like material & 8 & 110 & $2.9(0-9.1)$ \\
\hline 9-30 Nov 1982 & 80 & Aggregate-like material & 13 & 162 & $2.2(0-9.1)$ \\
\hline 9-30 Nov 1982 & 80 & Zooplankton pellet & 8 & 111 & $1.9(0-9.1)$ \\
\hline 9-30 Nov 1982 & 120 & Zooplankton pellet & 9 & 108 & $1.9(0-9.1)$ \\
\hline 9-30 Nov 1982 & 140 & Crab pellet & 7 & 103 & $1.4(0-10)$ \\
\hline 9-30 Nov 1982 & 400 & Pellet/algal cell ${ }^{\mathrm{b}}$ & 13 & 112 & $0.7(0-9.1)$ \\
\hline 9-30 Nov 1982 & $100^{\mathrm{c}}$ & Salp gut & 8 & 106 & $1.6(0-7.1)$ \\
\hline 9-30 Nov 1982 & $100^{\mathrm{c}}$ & Salp pellet & 8 & 127 & $3.7(0-10.5)$ \\
\hline
\end{tabular}

(from Table 1 of Alldredge \& Silver 1988). Therefore, based upon (1) average bacterial abundances from sinking particles (data from Table 5 of Alldredge \& Silver 1988) and (2) the correction factors of 2.33 to 10.0 from culture data, then a range of 7 to $31 \%$ (value from $30 \mathrm{~m}$ depth data in Table 2) or 1.2 to $5.1 \times 10^{6}$ particulate-associated bacteria $1^{-1}$ of near-surface seawater and a range of 5 to $20 \%$ (average of all values below $30 \mathrm{~m}$ in Table 2 ) or $2.5 \times 10^{5}$ to $1.0 \times 10^{6}$ particulateassociated bacteria $1^{-1}$ from deeper waters appear to be infected with phage.

The broad range of phage-infected bacteria in the particulate samples examined is likely a reflection of the diverse sources of bacterial communities that encounter and inhabit sinking particles. For example, discarded feeding structures of gelatinous zooplankton act as 'harvesters' of other particles and free-living bacteria because of the feeding mode of the zooplankton producing them (Alldredge \& Silver 1988), while fresh fecal pellets would contain enteric and digestion-resistant bacteria (Pomeroy \& Diebel 1980). The numbers and types of microorganisms inhabiting sinking particles change with the age of the particles, such that these microbial communities undergo successional changes (Pomeroy \& Diebel 1980). The diverse history of sinking particles in the ocean is reflected in the fact that bacterial abundances in sinking particles range over 5 orders of magnitude (Alldredge \& Silver 1988). Additionally, sediment trap material collected from even the same depth and site can represent sinking particles of varying age and origin, so that may also be reflected in the wide range of infected bacteria observed. The oceanographic conditions for the VERTEXI station (Table 1) were characteristic of the late upwelling season with surface water temperatures of 13 to $15^{\circ} \mathrm{C}$ and high chlorophyll a concentrations of $20 \mathrm{mg} \mathrm{m}^{-3}$ (Karl \& Knauer 1984). The VERTEX II and III stations were within the same general location, off the coast of Mexico (Table 1), and were characterized by relatively warm surface temperatures $\left(26\right.$ to $\left.28^{\circ} \mathrm{C}\right)$, moderate chlorophyll a concentrations and a well-developed, broad (120 to $850 \mathrm{~m}$ ) oxygen minimum layer (Karl \& Knauer 1984, Knauer et al. 1984). Both of these locations appear to have been particularly dynamic sites of sinking particle formation and flux which may be reflected in the varied percentage of infected cells present.

Fig. 1. Electron micrographs of viruses associated with sinking particles. (a) Large array of over 100 viruses, many of which possess antennae and exhibit heads devoid of nucleic acids as indicated by the strongly-straining protein coat without internal material (arrow); in unidentifiable material at $120 \mathrm{~m}$ (VERTEX II). (b) Larger, eukaryotic viruses (arrow), diameters averaging 200 nm, clustered near a diatom; in salp fecal pellet from upper $100 \mathrm{~m}$ plankton tow (VERTEX III). (c) Seven tailed viruses attached by the tails and forming a 'rosette', protein coat and striations on tail particularly evident in one virus (arrow), angle of section demonstrates that some of the phage are at the plane of the section (strongly-staining) while other phage are below the section plane (weakly-staining); in zooplankton fecal pellet at $120 \mathrm{~m}$ (VERTEX III). (d) Cluster of 40 virus particles; many of the viruses are tailed (arrow); in zooplankton fecal pellet at $80 \mathrm{~m}$ (VERTEX III). (e) Cluster of 40 (visible) viruses within one end of recently lysed cell; in zooplankton fecal pellet at $50 \mathrm{~m}$ (VERTEX I). (f) Cell with cell membrane still intact and containing 38 (visible) viruses, protein coat evident in some of the viruses (arrow); in unidentifiable material at $60 \mathrm{~m}$ (VERTEX II). Scale bars $=0.1 \mu \mathrm{m}$ except (a) and (b) where scale bars $=1.0 \mu \mathrm{m}$ 

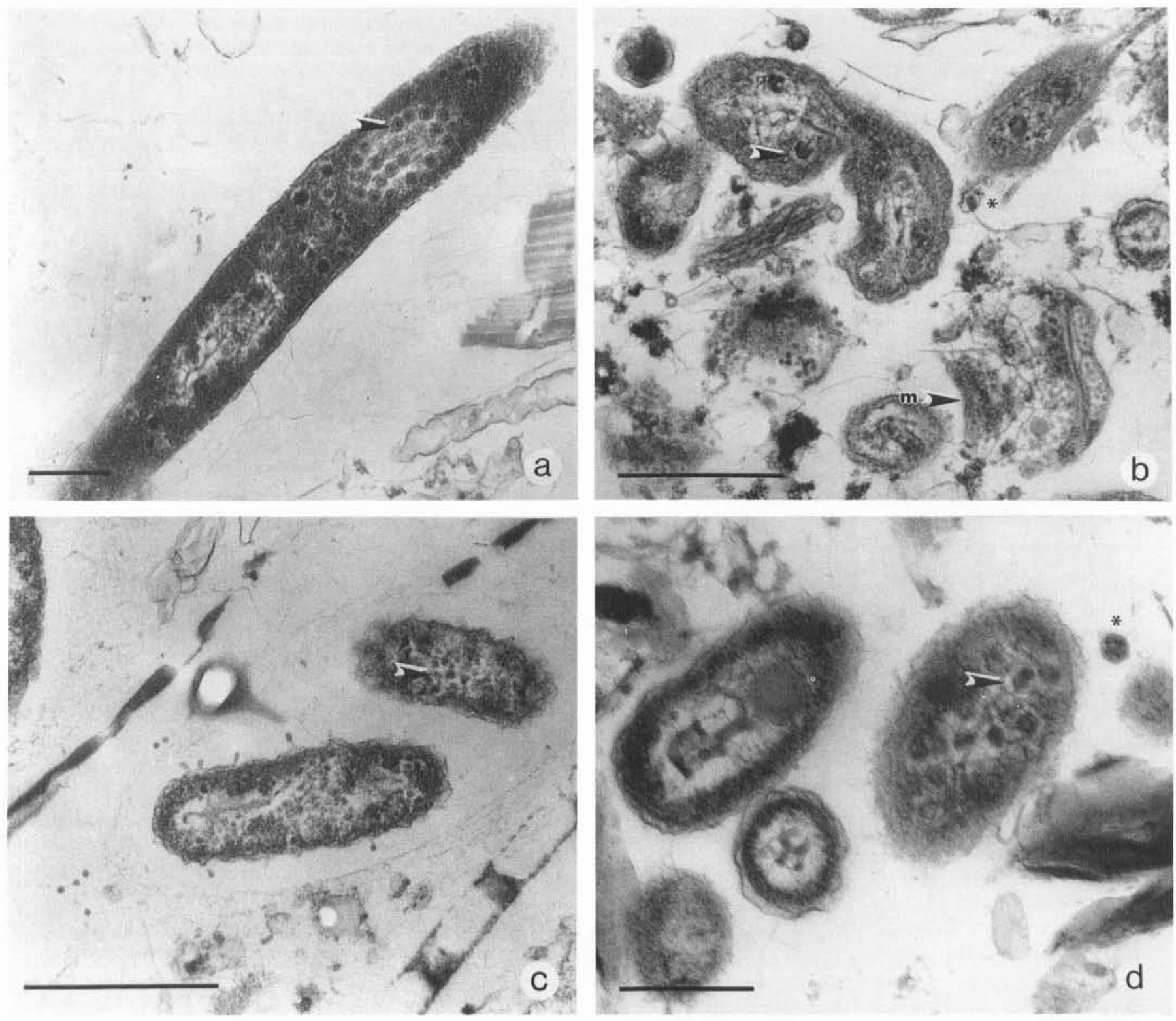

Fig. 2. Electron micrographs of bacteriophage-infected bacteria in sinking particles. (a) Large, rod-shaped bacterium (diameter approximately $1.08 \mu \mathrm{m}$ ) with ca 30 mature phage forming at one end of the cell (arrow); in salp fecal pellet from upper $100 \mathrm{~m}$ plankton tow (VERTEX III). (b) Bacterium with a few phage particles appearing in the cell (arrow); tailed virus adjacent to the infected cell (asterisk). Methylotrophs (m) did not appear phage-infected but were often observed in a partially lysed state in sinking particles; in zooplankton fecal pellet at $80 \mathrm{~m}$ (VERTEX III). (c) Two rod-shaped bacteria with phage filling the cells (arrow), both cells surrounded by a mucilaginous envelope; in zooplankton fecal pellet at $120 \mathrm{~m}$ (VERTEX III). (d) A phageinfected bacterium adjacent to 2 uninfected cells, protein coat particularly evident in some of the phage (arrow). A free virus adjacent to infected cell (asterisk); in unidentifiable material at $30 \mathrm{~m}$ (VERTEX II). Scale bars $=0.5 \mu \mathrm{m}$ except (a) where scale bar $=1.0 \mu \mathrm{m}$

Other studies of particulate-associated bacteria have noted declines in bacterial numbers. Ducklow et al. (1985) observed decreases, over $100 \mathrm{~d}$, of both attached and free-living bacterial abundances in continental slope sediment trap material from the Middle Atlantic Bight and suggested that the decline in cell numbers may have been due to predation or autolysis. We do not know whether bacterivores accounted for the decline in bacterial numbers in these studies; even knowing the bacterivore abundances would not let us know the extent of bacterivore grazing on particles. It is likely that both protozoan predation and viral lysis occurred simultaneously on particles since the time scales for both forms of mortality are similar. TEM examination of 

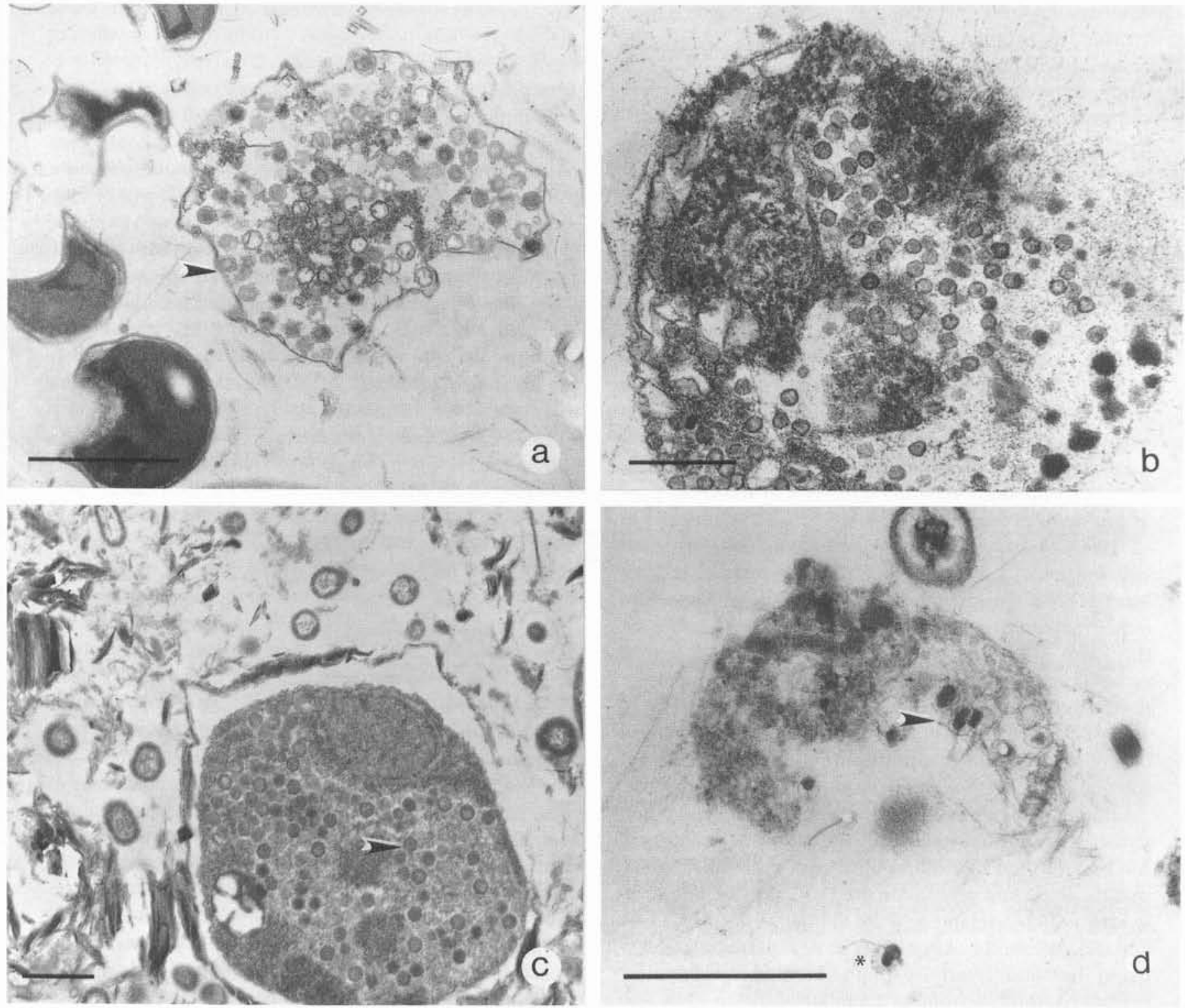

Fig. 3. Electron micrographs of virus-infected eukaryotic cells in sinking particles. (a) Eukaryotic cell full of viruses but with cell membrane still intact (arrow); none of the 'Chlorella-like' cells, adjacent to infected cell, appeared infected with viruses; in unidentifiable material at $30 \mathrm{~m}$ (VERTEX II). (b) Eukaryotic cell (diameter ca $5 \mu \mathrm{m}$ ) containing many virus particles but with some of the cell membrane and organelles still present; in crab fecal pellet at $140 \mathrm{~m}$ (VERTEX III). (c) Diatom (diameter ca 6 um) completely filled with viruses (arrow) but with nucleus, cell wall and frustule clearly intact; in zooplankton fecal pellet at $50 \mathrm{~m}$ (VERTEX I). (d) Remains of eukaryotic cell in further state of degradation but with virus particles (arrow) still associated with cytoplasmic material; free virus adjacent to infected cell (asterisk); in unidentifiable material at $80 \mathrm{~m}$ (VERTEX III). Scale bars $=$ $1.0 \mu \mathrm{m}$ except (b) where scale bar $=0.5 \mu \mathrm{m}$

bacterial cells in sinking particles is one way to investigate if mortality is due to viral lysis because the mortality agent in viral lysis is directly observable as phage within the host.

Viral lysis of free-living bacteria and particulateassociated bacteria may be causally linked because of the ecology of viruses in the water column and on particulate matter. Viruses, as charged colloidal particles, will reversibly adsorb to particulate matter such as sinking particles (Bitton \& Mitchell 1974). The protein coat of a virus has often been thought to be an evolutionary strategy to protect the nucleic acid from inactivation. However, particulate material appears to further protect viruses because virus survival rates are enhanced on particulate matter (reviewed in Gerba \& Schaiberger 1975, Kapuscinski \& Mitchell 1980). Additionally, in the ocean, viruses may become concentrated because of the 'harvesting' activity of gelatinous 
zooplankton and increase the survival rate of those viruses associated with the discarded gelatinous material. Although viruses were not enumerated in this study, they were often found aggregated or clustered, suggestive of mechanisms which enhance virus aggregation (Young \& Sharp 1977) in sinking particles. The mechanisms which enhance virus survival may not only influence the frequency of host encounter and successful host infection but link viral lysis of the freeliving bacteria and particulate-associated bacteria.

Viral lysis results in the direct release of organic matter which contributes to the 'dissolved' organic carbon (DOC) pool. DOC is operationally defined as organic matter that passes a particular filter pore size, typically a $0.45 \mu \mathrm{m}$ membrane filter or a glass fiber filter with an effective pore size of ca $0.7 \mu \mathrm{m}$. Viruses and the accompanying macromolecules released from cell lysis may comprise a component of the high molecular weight compounds recently observed in the DOC pool in the open ocean (Sugimura \& Suzuki 1988, Koike et al. 1990). As such, viruses, macromolecules and small cellular debris (all typically $<0.2 \mu \mathrm{m}$ ) would be considered DOC, although all of these lysis products could be either colloidal or truly dissolved. More specifically, there are 2 general modes of phage replication with either (1) complete disassembly of host chromosome or (2) the presence of an intact host chromosome (Hayes 1976) and each mode of lysis could result in the release of not only viruses, but different molecular weight fractions of host DNA (megadaltons), RNA and protein.

Little is known about what is actually released when a marine bacterium lyses but a hypothetical example of the contribution of 2 major classes of macromolecules, nucleic acids and protein, to the DOC pool will demonstrate the potential importance of this process. As a first approximation, for every $10 \%$ of a population of freeliving bacteria lysed by phage, assuming a typical marine bacterium contains $2.5 \mathrm{fg}$ DNA, $2.9 \mathrm{fg}$ RNA and $14.8 \mathrm{fg}$ protein (mean values from $<0.07 \mu \mathrm{m}^{3}$ cells from Table 5 of Simon \& Azam 1989), then at free-living bacterial abundances of $5 \times 10^{8} 1^{-1}$ (Fuhrman et al. 1989, Proctor \& Fuhrman 1990), ca 270 ng nucleic acids $1^{-1}$ of seawater and $575 \mathrm{ng}$ proteins $1^{-1}$ of seawater would be released, within one bacterial generation (1 to 15 d: Fuhrman et al. 1989, Simon \& Azam 1989), from cell lysis.

Similarly, for every $10 \%$ of a population of particulate-associated bacterial population lysed by phage, assuming biovolumes of $0.93 \mu^{3}$ (Alldredge et al. 1986) and $3.3 \mathrm{fg}$ DNA, $4.2 \mathrm{fg}$ RNA and $24.2 \mathrm{fg}$ proteins per bacterium (mean from values for 0.70 and $1.0 \mu \mathrm{m}^{3}$ cells from Table 5 of Simon \& Azam 1989) and average bacterial abundances of $1.1 \times 10^{7} 1^{-1}$ (average of particulate-associated bacteria in near surface and deeper waters; Table 5 of Alldredge \& Silver 1988), ca $8.3 \mathrm{ng}$ nucleic acids $1^{-1}$ of seawater and $26.6 \mathrm{ng}$ proteins $\mathrm{l}^{-1}$ of seawater would be released (within one generation of particulate-associated bacteria: 2 to $77 \mathrm{~d}$; Ducklow et al. 1985, Alldredge et al. 1986) from cell lysis.

Together, cell lysis of only $10 \%$ of the population of free-living and particle-associated bacteria could contribute ca $1 \mu \mathrm{g}$ of 'DOC' (here considering only nucleic acids and proteins) $l^{-1}$ of seawater, in the form of high molecular weight compounds, within one bacterial generation, mostly from the free-living cells. We did not observe any extruded or budding viruses in our TEM micrographs, although it is quite possible that nonlytic release of viruses occurs. Such viruses also contain nucleic acid and protein, and would likely contribute more to the 'DOC' release by bacteria. Our estimate of DOC release is conservative since (1) it assumes that host assimilation of substrates ceases immediately upon viral infection, and (2) it only includes DNA, RNA and protein. Although these nitrogen- and phosphorus-rich macromolecules are available for bacterial nutrition (Paul et al, 1987, Rosso \& Azam 1987, Karl \& Bailiff 1989), the relatively long turnover times of even labile macromolecules in some ocean locations (e.g. $32 \mathrm{~d}$ for dissolved DNA in the open ocean; Paul et al. 1987) suggest that the products of cell lysis could persist long enough to play a role in particle formation, as discussed below.

Large macromolecules, such as nucleic acids and proteins, can be important as polymer bridges between particles. Viral lysis results in the release of viruses as well as cell walls and membranes, other large cellular fragments and intracellular polymers such as proteins and nucleic acids. Many of the virus aggregates observed associated with host cell remains in the VERTEX sediment trap material look remarkably like the remnants of Escherichia coli cell lysis observed by Cota-Robles (1964). Most of the cellular components released from lysis have been suggested as important 'biological glues' to enhance aggregation and promote sinking particle formation (Alldredge \& Silver 1988). In particular, dissolved DNA appears to be an effective aggregation agent in various microbial communities (Vallom \&McLoughlin 1984 ) indicating that products of viral lysis may play an importnt role in sinking particle dynamics. Moreover, viral lysis may be a factor to consider in particulate formation because of the size of particles produced. Some workers (McCave 1986) indicate that submicron particles in the ocean may be important as condensation nuclei for the initiation of organic aggregation and, at virus abundances of up to $10^{11} 1^{-1}$ (Bergh et al. 1989, Bratbak et al. 1990, Proctor \& Fuhrman 1990), viruses may be one source of these condensation nuclei.

Viral lysis of particle-associated communities has many implications for sinking organic matter where viruses can be indirect agents of carbon loss from 
particulate matter. It has been suggested that particleassociated bacteria play a direct role in particle dissolution by the hyperproduction of extracellular hydrolases which solubilize the sinking particles (Cho \& Azam 1988). If virus infection is a significant cause of bacterial mortality, exohydrolase production by particle-associated bacteria may actually be a defense against infectious viruses. Sinking particle disaggregation and dissolution may only be a byproduct of this defense mechanism.

An additional observation of potential importance to productivity and carbon flux estimates was the presence of eukaryotic cells in the sediment trap samples, particularly phytoplankton, that appeared infected with viruses. Viral lysis has been reported for both cultures and natural populations of marine phytoplankton such as prasinophytes (Moestrup \& Thomsen 1974, Pearson \& Norris 1974, Pienaar 1976, Mayer \& Taylor 1979), cryptophytes (Pienaar 1976), haptophytes (Pearson \& Norris 1974), chrysophytes (Sieburth et al. 1988) and cyanobacteria (Proctor \& Fuhrman 1990). The presence of virus-infected phytoplankton in the VERTEX samples along with the cited reports on viruses in other marine phytoplankton suggests that viral lysis may be a significant mode of mortality for phytoplankton communities. Moreover, viral lysis of larger $(>10 \mu \mathrm{m})$ phytoplankton, as we observed in VERTEX samples, should receive special attention because they appear to be particularly important contributors to particle flux out of surface waters (Michaels \& Silver 1988).

In summary, viral lysis increases the complexity of the marine microbial food web in the ocean by including a process for the direct release of nitrogen- and phosphorus-rich high and low molecular weight organic matter from free and aggregated microorganisms. In turn, lysis products may be a source of bacterial nutrition and may play roles in particle formation and the vertical distribution of nutrients. Thus, viral lysis may have several important implications for material and energy cycling in the ocean.

Acknowledgements. We gratefully acknowledge Drs Mary Silver and Marcia Gowing, Institute for Marine Studies, University of California at Santa Cruz, for generously allowing access to VERTEX samples for the purposes of this study. The suggestions of Dr Mary W. Silver; Dr Cindy Lee, Marine Science Research Center, State University of New York, Stony Brook; Dr James Novitsky, Department of Biology, Dalhousie University and 3 anonymous reviewers greatly improved the text.

\section{LITERATURE CITED}

Ahrens, R. (1971). Untersuchungen zur Verbreitung von Phagen der Gattung Agrobacterium in der Ostsee. Kieler Meeresforsch. 27: 102-112

Alldredge, A. L., Cole, J. J., Caron, D. A. (1986). Production of heterotrophic bacteria inhabiting macroscopic organic aggregates (marine snow) from surface waters. Limnol. Oceanogr. 31: 68-78

Alldredge, A. L., Silver, M. W. (1988). Characteristics, dynamics and significance of marine snow. Prog. Oceanogr. 20: 41-82

Baross, J. A., Liston, J., Morita, R. Y. (1978). Incidence of Vibrio parahaemolyticus and other Vibrio bacteriophages in marine samples. Appl. environ. Microbiol. 36: 492-499

Bergh, Ø., Børsheim, K. Y., Bratbak, G., Heldal, M. (1989). High abundance of viruses found in aquatic environments. Nature, Lond. 340: 467-468

Bitton, G., Mitchell, R. (1974). Effects of colloids on the survival of bacteriophages in seawater. Water Res. 8: 227-229

Børsheim K. Y., Bratbak, G., Heldal, M. (1990). Enumeration and biomass estimation of planktonic bacteria and viruses by transmission electron microscopy. Appl. environ. Microbiol. 56: 352-356

Bratbak, G., Heldal, M., Norland, S., Thingstad, T. F. (1990). Viruses as partners in spring bloom trophodynamics. Appl. environ. Microbiol. 56: 1400-1405

Caron, D. A., Davis, P. G., Madin, L. P., Sieburth, J. McN. (1986). Enrichment of microbial populations in macroaggregates (marine snow) from surface waters of the North Atlantic. J. mar. Res. 44: 543-565

Chaina, P. N. (1965). Some recent studies of marine bacteriophages. J. gen. Microbiol. 41: XXV

Cho, B. C., Azam, F. (1988). Major role of bacteria in biogeochemical fluxes in the ocean's interior. Nature, Lond. 332: 441-443

Cota-Robles, E. H. (1964). Electron microscopy of 'lysis from within' of Escherichia coli by coliphage T2. J. Ultrastruct. Res. 11: 112-122

Ducklow, H. W., Hill, S. M., Gardner, W. D. (1985). Bacterial growth and the decomposition of particulate organic matter collected in sediment traps. Cont. Shelf Res. 4: 445-464

Emiliani, C. (1982). Extinctive evolution: extinctive and competitive evolution combine into a unified model of evolution. J. theor. Biol. 97: 13-33

Fournier, R. O. (1970). Studies on pigmented microorganisms from aphotic marine environments. Limnol. Oceanogr. 15: $675-682$

Fuhrman, J. A., Sleeter, T. D., Carlson, C. A., Proctor, L. M. (1989). Dominance of bacterial biomass in the Sargasso Sea and its ecological implications. Mar. Ecol. Prog. Ser. 57: 207-217

Gerba, C. P., Schaiberger, G. E. (1975). Effect of particulates on virus survival in seawater. J. Water Pollut. Control. Fed. 47: 93-103

Gowing, M. M., Silver, M. W. (1983). Origins and microenvironments of bacteria mediating fecal pellet decomposition in the sea. Mar. Biol. 73: 7-16

Gowing, M. M., Silver, M. W. (1985). Minipellets: a new and abundant size class of marine fecal pellets. J, mar. Res. 43: 395-418

Harris, R. H., Mitchell, R. (1973). The role of polymers in microbial aggregation. Ann. Rev. Microbiol. 27: 27-50

Hayes, W. (1976). The genetics of bacteria and their viruses, 2nd edn. John Wiley and Sons, New York

Hidaka, T. (1971). Isolation of marine bacteriophages from sea water. Bull. Jap. Soc. scient Fish 37: 1199-1206

Hidaka, T. (1977). Detection and isolation of marine bacteriophage systems in the Southwestern part of the Pacific Ocean. Mem. Fac. Fish., Kagoshima Univ. 26: 55-62

Johnson, R. M. (1968). Characteristics of a marine vibriobacteriophage system. J. Ariz. Acad. Sci. 5: 28-33

Kakimoto, D., Nagatomi, H. (1972). Bacteriophages of Kinko Bay. Bull. Jap. Soc. scient. Fish. 38: 271-278 
Kapuscinski, R. B., Mitchell, R. (1980). Processes controlling virus inactivation in coastal waters. Water Res. 14: 363-371

Karl, D. M., Bailiff, M. D. (1989). The measurement and distribution of dissolved nucleic acids in aquatic environments. Limnol. Oceanogr. 34: 543-558

Karl, D. M., Knauer, G. A. (1984). Vertical distribution, transport and exchange of carbon in the Northeast Pacific Ocean: evidence for multiple zones of biological activity. Deep Sea Res. 31: 221-243

Kellenberger, E. (1961). Vegetative bacteriophage and the maturation of the virus particles. Adv. Virus Res. 7: 1-61

Kellenberger, E., Sechaud, J., Ryter, A. (1959). Electron microscopical studies of phage replication. IV. The establishment of the DNA pool of vegetative phage and the maturation of phage particles. Virology 8: 478-490

Knauer, G. A., Martin, J. H., Bruland, K. W. (1979). Fluxes of particulate carbon, nitrogen and phosphorus in the upper water column of the northeast Pacific. Deep Sea Res. 26: 97-108

Knauer, G. A., Martin, J. H., Karl, D. M. (1984). The flux of organic material out of the euphotic zone. In: Global Ocean Flux Studies. Proceedings of a Workshop, Woods Hole, MA. National Academy Press, Washington, D.C., p. $136-150$

Kriss, A. E., Rukina, E. A. (1947). Bacteriophages in the sea. Dokl. Akad. Nauk SSSR 57: 833-836

Koike, I., Hara, S., Terauchi, K., Kogure, K. (1990). Role of submicrometre particles in the ocean. Nature, Lond. 345: 242-244

Lycke, E., Magnusson, S., Lund, E. (1965). Studies on the nature of the virus inactivating capacity of seawater. Arch. ges. Virusforsch. 17: 409-413

McCave, I. N. (1986). Particle size spectra and aggregation in, and removal from, the oceans. In: Aggregate dynamics in the sea. Proceedings of a Workshop, Arlington, VA. Office of Naval research and Amer. Inst. Biol. Sci., Washington, D.C., p. 90-108

McManus, G. B., Fuhrman, J. A. (1988). Control of marine bacterioplankton populations: measurement and significance of grazing. Hydrobiol. 159: 51-62

Martin, J. H., Knauer, G. A., Karl, D. M., Broenkow, W. W. (1987). VERTEX: carbon cycling in the northeast Pacific. Deep Sea Res. 34: 267-285

Mayer, J. A., Taylor, F. J. R. (1979). A virus which lyses the marine nanoflagellate Micromonas pusilla. Nature, Lond. 281: 299-301

Michaels, A. F., Silver, M. W. (1988). Primary production, sinking fluxes and the microbial food web. Deep Sea Res. 35: $473-490$

Moebus, K., Nattkemper, H. (1981). Bacteriophage sensitivity patterns among bacteria isolated from marine waters. Helgoländer Meeresunters. 34: 375-385

Moestrup, D., Thomsen, H. R. (1974). Virus-like particles (VLPs) in a marine prasinophyte. Protoplasma 81: 247-252

Pace, M. L. (1988). Bacterial mortality and the fate of bacterial production. Hydrobiol. 159: 41-49

Paul, J. H., Jeffrey, W. D., DeFlaun, M. F. (1987). Dynamics of extracellular DNA in the marine environment. Appl. environ. Microbiol. 53: 170-179

Pearson, B. R., Norris, R. E. (1974). Intranuclear virus-like particles in the marine alga Platymonas sp. (Chlorophyta, Prasinophyceae). Phycologia 13: 5-9

Pienaar, R. N. (1976). Virus-like particles in three species of phytoplankton from San Juan Island, Washington. Phycologia 15: 185-190

Pomeroy, L. R., Diebel, D. (1980). Aggregation of organic matter by pelagic tunicates. Limnol. Oceanogr. 25: 643-652

Pomeroy, L. R., Hanson, R. B., McGillivary, P. A., Sherr, B. F. Kirchman, D. K., Diebel, D. (1984). Microbiology and chemistry of fecal products of pelagic tunicates: rates and fates. Bull. mar. Sci. 35: 426-439

Proctor, L. M., Fuhrman, J. A. (1990). Viral mortality of marine bacteria and cyanobacteria. Nature, Lond. 343: 60-62

Proctor, L. M., Fuhrman, J. A., Ledbetter, M. C. (1988). Marine bacteriophages and bacterial mortality. EOS 69: $1111-1112$

Riley, G. A. (1970). Particulate matter in seawater. Adv, mar. Biol. 8: 1-118

Rosso, A. L., Azam, F. (1987). Proteolytic activity in coastal oceanic waters: depth distribution and relationship to bacterial populations. Mar. Ecol. Prog. Ser. 41: 231-240

Sieburth, J. McN. (1979). Sea microbes. Oxford Univ. Press London

Sieburth, J. McN., Johnson, P. W., Hargraves, P. E. (1988) Ultrastructure and ecology of Aureococcus anophagefferens gen. et sp. nov. (Chrysophyceae): the dominant picoplankter during a bloom in Narragansett Bay, Rhode Island, summer, 1985. J. Phycol. 24: 416-425

Silver, M. W., Alldredge, A. L. (1981). Bathypelagic marine snow: deep-sea algal and detrital community. J. mar. Res. 39: $501-530$

Silver, M. W., Bruland, K. W. (1981). Differential feeding and fecal pellet composition of salps and pteropods, and the possible origin of the deep-sea flora and 'olive-green' cells. Mar. Biol. 62: 263-273

Silver, M. W., Gowing, M. M., Brownlee, D. C., Corliss, J. O. (1984). Ciliated protozoa associated with oceanic sinking detritus. Nature, Lond. 309: 246-248

Simon, M., Azam, F. (1989). Protein content and protein synthesis rates of planktonic marine bacteria. Mar. Ecol. Prog. Ser. 51: 201-213

Spencer, R. (1963). Bacterial viruses in the sea. In: Oppenheimer, C. H., (ed.) Symposium on marine microbiology. Charles Thomas Publ., Springfield, Illinois

Sugimura, Y., Suzuki, Y. (1988). A high-temperature catalytic oxidation method for the determination of non-volatile dissolved organic carbon in seawater by direct injection of a liquid sample. Mar. Chem. 24: 105-131

Suttle, C. A., Chan, A. M., Cottrell, M. T. (1990). Viruses infect marine phytoplankton and reduce primary production by up to $80 \%$. EOS 71: 162

Torella, F., Morita. R. Y. (1979). Evidence by electron micrographs for a high incidence of bacteriophage particles in the waters of Yaquina Bay, Oregon: ecological and taxonomical implications. Appl. environ. Microbiol. 37: $774-778$

Valentine, A. F., Chapman, G. B. (1966). Fine structure and host-virus relationship of a marine bacterium and its bacteriophage. J. Bact. 92: 1535-1554

Vallom, J. K., McLoughlin, A. J. (1984). Lysis as a factor in sludge formation. Water Res. 18: 1523-1528

Young, D. C., Sharp, D. G. (1977). Polio virus aggregates and their survival in water. Appl. environ. Microbiol. 33: 168-177

Zachary, A. (1978). An ecological study of bacteriophages of Vibrio natriegens. Can. J. Microbiol. 24: 321-324

Manuscript first received: April 5, 1990

Revised version accepted: September 14, 1990
This article was presented by Dr O. Holm-Hansen, La Jolla California, USA 